\title{
Relationship between somatic cell count and milk yield in different stages of lactation
}

\author{
C. Hagnestam-Nielsen, ${ }^{* 1}$ U. Emanuelson, † B. Berglund, ${ }^{*}$ and E. Strandberg* \\ *Swedish University of Agricultural Sciences, Department of Animal Breeding and Genetics, PO Box 7023, SE-750 07 Uppsala, Sweden \\ †Swedish University of Agricultural Sciences, Department of Clinical Sciences, PO Box 7054, SE-750 07 Uppsala, Sweden
}

\begin{abstract}
The association between somatic cell count (SCC) and daily milk yield in different stages of lactation was investigated in cows free of clinical mastitis $(\mathrm{CM})$. Data were recorded between 1989 and 2004 in a research herd, and consisted of weekly test-day (TD) records from 1,155 lactations of Swedish Holstein and Swedish Red cows. The main data set (data set A) containing 36,117 records excluded TD affected by CM. In this data set, the geometric mean SCC was 55,000 and 95,000 cells/ $\mathrm{mL}$ in primiparous and multiparous cows, respectively.
\end{abstract} A subset of data set A (data set B), containing 27,753 records excluding all TD sampled in lactations affected by CM, was created to investigate the effect of subclinical mastitis (SCM) in lactations free of CM. Daily milk yields were analyzed using a mixed linear model with lactation stage; linear, quadratic and cubic regressions of $\log _{2}$-transformed and centered SCC nested within lactation stage; weeks in lactation; TD season; parity; breed; pregnancy status; year-season of calving; calving, reproductive, metabolic and claw disorders; and housing system as fixed effects. A random regression was included to further improve the modeling of the lactation curve. Primiparous and multiparous cows were analyzed separately. The magnitude of daily milk loss associated with increased SCC depended on stage of lactation and parity, and was most extensive in late lactation irrespective of parity. In data set A, daily milk loss at an SCC of 500,000 cells $/ \mathrm{mL}$ ranged from 0.7 to $2.0 \mathrm{~kg}$ (3 to $9 \%$ ) in primiparous cows, depending on stage of lactation. In multiparous cows, corresponding loss was 1.1 to $3.7 \mathrm{~kg}$ (4 to $18 \%$ ). Regression coefficients of primiparous cows estimated from data set B were consistent with those obtained from data set A, whereas data set B generated more negative regression coefficients of multiparous cows suggesting a higher milk loss associated with increased SCC in lactations in which the cow did not develop CM. The 305-d milk loss in the

Received September 16, 2008.

Accepted January 21, 2009.

${ }^{1}$ Corresponding author: Christel.Nielsen@hgen.slu.se average lactation affected with SCM was $155 \mathrm{~kg}$ of milk (2\%) in primiparous cows and $445 \mathrm{~kg}$ of milk (5\%) in multiparous cows. It was concluded that multiparous cows in late lactation can be expected to be responsible for the majority of the herd-level production loss caused by SCM, and that preventive measures need to focus on reducing the incidence of SCM in such cows.

Key words: dairy cow, somatic cell count, subclinical mastitis, production loss

\section{INTRODUCTION}

Subclinical mastitis (SCM) is associated with increased SCC and has several negative consequences. The risk of clinical mastitis $(\mathbf{C M})$ increases with increasing SCC (Beaudeau et al., 1998; Steeneveld et al., 2008). Even mild cases of CM cause increased responsiveness to pain and affected cows become hypersensitized to stimuli normally considered innocuous (Fitzpatrick et al., 1998). The herd-level economic loss brought about by SCM is substantial and has been reported to be even larger than that caused by CM (Huijps et al., 2008). In addition, high SCC is associated with reduced processing ability of milk; it reduces cheese yield (Politis and Ng-Kwai-Hang, 1988) and decreases the shelf-life of consumer milk (Ma et al., 2000). Reduced animal welfare, economic losses, and poor milk quality, consequently, form incentives to reduce the incidence of SCM.

Clearly, mastitis control is of paramount importance. Preventive measures are, however, associated with extra costs, and must therefore be evaluated against the economic loss caused by mastitis. The main component of the economic loss associated with SCM is reduced milk production in affected cows (Huijps et al., 2008). Thus, the cost of SCM will largely depend on the extent of the associated yield loss. Accurate estimates of the effect of SCM on production, in different stages of lactation and parities, are thus necessary for supporting strategic decision-making regarding mastitis control in dairy herds.

The relationship between SCM and milk production has usually been investigated in terms of effects associ- 
ated with changes in SCC, and such studies are abundant. Clear effect of parity as well as stage of lactation on the magnitude of milk loss has been reported (Hortet and Seegers, 1998; Hortet et al., 1999; Bennedsgaard et al., 2003). With a few exceptions (Deluyker et al., 1993; Hortet et al., 1999; Bennedsgaard et al., 2003), most studies have not accounted for $\mathrm{CM}$ as a confounder. The validity of estimates of the effect of increased SCC on milk yield may be questioned if the analyses fail to control for CM, because the observed effect may in fact be attributed to $\mathrm{CM}$ rather than SCM. To properly assess the yield loss caused by SCM, the analyses must therefore control for CM.

The aim of the present study was to estimate the production loss associated with SCM in different stages of lactation, taking the effect of CM into consideration.

\section{MATERIALS AND METHODS}

\section{Animals and Management}

Test-day (TD) records that were collected at weekly intervals between November 1989 and April 2004 in the research herd of the Department of Animal Breeding and Genetics were available. Swedish Red (SR, n $=303)$ and Swedish Holstein $(\mathbf{S H}, \mathrm{n}=194)$ cows of parities 1 to 9 were included in the study. In 2004, the average yearly production of the $\mathrm{SR}$ and $\mathrm{SH}$ cows in the herd was 8,921 and $10,626 \mathrm{~kg}$ of milk, respectively. These production levels were slightly above the national averages for the breeds. The SR cows were in a selection experiment. They were bred for either high (n $=146)$ or low $(\mathrm{n}=157)$ fat content in their milk, while maintaining the same total energy production.

The lactational incidence risk (lactations with at least one case of $\mathrm{CM}$ divided by the total number of lactations at risk) of $\mathrm{CM}$ was 19.9 and $28.9 \%$ in primiparous and multiparous cows, respectively. All cases were diagnosed by a veterinarian. Treatment decisions were made according to a standard operating protocol based on stage of lactation as well as possible designation for culling. The pathogen frequency in the herd is described previously by Hagnestam et al. (2007).

The research herd was kept at 2 locations during the study period. Before 1992, the herd was kept on a farm with tie-stall housing. The current farm has a free-stall barn $(\mathrm{n}=50)$ and a tie-stall barn $(\mathrm{n}=50)$. Cows from the old facilities were placed in the tie-stall barn on the new farm to facilitate their transition in 1992. Before 2001, cows were kept in one barn throughout lactation. Starting in 2001, cows were kept in the free-stall barn for at least $12 \mathrm{wk}$ after calving, and were moved to the tie-stall barn as their production dropped below 25 and $35 \mathrm{~kg}$ of ECM in primiparous and multiparous cows, respectively. Cows with $\mathrm{CM}$ were kept in the tie-stall barn.

The cows were fed according to Swedish nutritional standards (Spörndly, 1999). In the first 16 wk of lactation, cows were fed ad libitum. Thereafter, they were fed a restricted ration based on production level and BW. In the tie-stall barn, cows were fed the total ration individually, whereas only concentrates were fed individually in the free-stall barn. Additional concentrates and roughage were supplied during the pasture period (May to September).

All cows were milked twice daily and were testmilked once a week. Test-day records were obtained by combining a.m. and p.m. samples according to the relative milk yield at respective occasion. Somatic cell count was measured in composite milk samples using a Fossomatic 5000 (Foss, Hillerød, Denmark). The results were rounded to the nearest 1,000 cells $/ \mathrm{mL}$.

\section{Data}

Lactations were truncated at $305 \mathrm{~d}$. Two data sets were created to investigate whether the estimated milk loss associated with increased SCC differed depending upon whether the data set excluded TD records in which the cow was affected by $\mathrm{CM}$ or excluded full lactations in which $\mathrm{CM}$ occurred.

Data Set $\boldsymbol{A}$. In data set A, TD records in which the cow was affected by CM were discarded. The International Dairy Federation (1997) proposes a lag time of 8 d between 2 subsequent cases of CM; that is, the first infection is assumed to last for $8 \mathrm{~d}$ and any infection occurring later is attributed to a new case. A case of CM was, therefore, assumed to last for $8 \mathrm{~d}$ following diagnosis. Data set A comprised 36,117 TD records collected in 1,155 lactations of primiparous and multiparous cows (467 and 688 lactations, 15,609 and 20,508 $\mathrm{TD}$, respectively). The average number of lactations per cow was $2.3 \pm 1.3$, and the mean number of TD records per lactation was $31.3 \pm 10.2$. The geometric mean SCC was 55,000 and 95,000 cells/mL in primiparous and multiparous cows, respectively. Descriptive statistics on SCC for data set A are shown in Table 1 for primiparous cows and in Table 2 for multiparous cows.

Data Set B. A subset of data set A (data set B) was created by excluding all lactations in which CM occurred. Data set B contained 27,753 TD records collected in 863 lactations of primiparous and multiparous cows (374 and 489 lactations, 12,811 and 14,942 TD, respectively). The average number of lactations per cow was $2.0 \pm 1.0$, and the mean number of TD records per lactation was $32.2 \pm 9.7$. 
Table 1. Descriptive statistics of SCC $\left(\times 10^{3}\right.$ cells $\left./ \mathrm{mL}\right)$ sampled from primiparous cows free of clinical mastitis at sampling (data set A)

\begin{tabular}{|c|c|c|c|c|c|c|}
\hline Item & \multicolumn{6}{|c|}{ Week of lactation } \\
\hline Records (n) & 421 & 2,460 & 3,054 & 3,080 & 2,888 & 3,706 \\
\hline \multicolumn{7}{|l|}{ SCC category } \\
\hline$\leq 50$ & 15.9 & 53.4 & 64.4 & 61.3 & 56.7 & 44.3 \\
\hline$\overline{5} 1$ to 100 & 25.2 & 20.1 & 16.1 & 18.2 & 20.0 & 24.8 \\
\hline 501 to 1,000 & 8.5 & 3.2 & 1.8 & 2.0 & 1.8 & 2.1 \\
\hline$>1,000$ & 8.1 & 2.4 & 1.4 & 1.2 & 1.3 & 1.7 \\
\hline
\end{tabular}

\section{Statistical Methods}

The effect of SCC on TD milk yield was estimated using a mixed linear model in PROC MIXED of SAS (SAS Version 9.1, SAS Institute Inc., Cary, NC). Because of the different shapes of their lactation curves, primiparous and multiparous cows were analyzed separately. For multiparous cows, the following model was used:

$\mathrm{TD}$ milk yield $=$ lactation stage $(1$ to 6$)+$ linear,

quadratic and cubic regressions on $\log _{2}$-transformed

and centered SCC, nested within lactation stage

+ weeks in lactation ( 1 to 19$)+$ TD season (1 to 6 )

+ parity $(2$ or $3+)+$ breed (SR-low, SR-high, SH)

+ pregnancy status (yes/no) + calving year-season $(1$

to 46$)+$ index for calving disorders (1 to 3 )

+ index for reproductive disorders $(1$ to 5$)+$ index

for metabolic disorders ( 1 to 5$)+$ index for claw

disorders (1 to 5$)+$ housing system (tie-stall,

free-stall, missing) + random regression function

describing the lactation curve, specific for each

lactation within cow + random residual.
Somatic cell count was $\log _{2}$-transformed and was subsequently centered on the median to decrease collinearity between the linear and power terms. Linear, quadratic, and cubic effects of $\log _{2}$-transformed SCC were nested within lactation stage, and significant $(P$ $<0.05)$ terms were included in the final model. Somatic cell count was nested within lactation stage (wk 1 to 2, 3 to 8,9 to 16,17 to 24,25 to 32 , and 33 to 44 ) rather than within the more-detailed variable weeks in milk, because this resulted in better model fit according to Akaike's information criterion. Weeks in lactation had 19 classes and was included in the model to provide more detail in the modeling of the general lactation curve. Thus, milk records collected within the first 8 wk of lactation were grouped into weekly intervals; records from wk 9 to 16 were grouped into 2 -wk periods, and records taken later than $17 \mathrm{wk}$ after calving were grouped into 4 -wk periods. To elaborate the description of the lactation curve even further, a random regression modeling the deviation of individual lactations from the general lactation curve was included. The logarithmic function described by Ali and Schaeffer (1987) was used because it provided best model fit (Akaike's information criterion):

$$
\mathrm{b}_{0}+\mathrm{b}_{1} \mathrm{c}+\mathrm{b}_{2} \mathrm{c}^{2}+\mathrm{b}_{3}(\ln 1 / \mathrm{c})+\mathrm{b}_{4}(\ln 1 / \mathrm{c})^{2}
$$

where $\mathrm{c}=\mathrm{DIM} / 305$ and

Table 2. Descriptive statistics of SCC $\left(\times 10^{3}\right.$ cells $\left./ \mathrm{mL}\right)$ sampled from multiparous cows free of clinical mastitis at sampling (data set A)

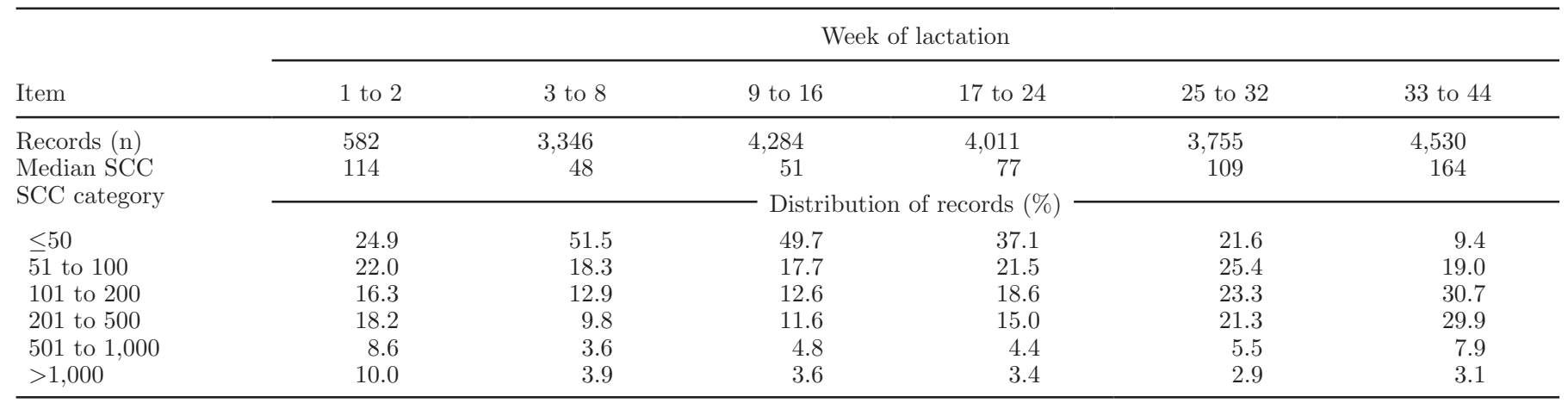




$$
\underset{\sim}{b} \sim N D(0, \underset{\sim}{V}) \text {, and } \underset{\sim}{V}=\left(\begin{array}{ccc}
\sigma_{b_{0}}^{2} & \cdots & \sigma_{b_{0} b_{4}} \\
& \ddots & \vdots \\
& & \sigma_{b_{4}}^{2}
\end{array}\right) \text {, }
$$

where $V$ is the variance-covariance matrix of the regression coefficients.

The "subject" option in the random statement was used to specify that observations were clustered within lactations. Complete independence is assumed between subjects, and hence the variance-covariance matrix for the random effects is block diagonal with identical blocks (Singer, 1998). The structure of these blocks was specified in the "type" option, and by stipulating an unstructured variance-covariance structure, we imposed separate variance and covariance on each of the components of the random part of the lactation curve.

Test-day season had 6 classes: January and February, March and April, May and June, July and August, September and October, and November and December. Pregnancy status indicated whether or not the cow was pregnant on the TD and was included because pregnancy is known to have negative effect on production (Olori et al., 1997; Roche, 2003).

Three calving seasons were defined: January to April, May to August, and September to December. Year and season of calving were pooled and analyzed as a combined variable comprising 46 classes.

Calving disorders, reproductive disorders, metabolic disorders, and claw disorders were included in the analyses to adjust for their effects as confounders, because they are associated with milk yield (Fourichon et al., 1999; Østergaard and Gröhn, 1999; Sogstad et al., 2007) and have, in some studies, been reported to predispose to mastitis (Dohoo and Martin, 1984; Bendixen et al., 1988; Sogstad et al., 2006). Calving disorders were dystocia (assistance by 2 persons or by a veterinarian) and stillbirth (calf born dead or dead within $24 \mathrm{~h}$ of birth). Reproductive disorders included retained placenta $(>24 \mathrm{~h})$, cystic ovarian disease $(>40$ d postpartum), metritis, endometritis, pyometra, and anestrus. Metabolic disorders constituted milk fever, ketosis, and displaced abomasum, whereas claw disorders included interdigital phlegmon, interdigital dermatitis, heel horn erosion, sole hemorrhage, sole ulcer, claw abscess, and laminitis. Dystocia, stillbirth, and retained placenta were diagnosed by the farm personnel. Claw disorders were diagnosed by a veterinarian or a professional hoof trimmer. Other disorders were diagnosed by a veterinarian. Test-day milk yield was related to the time of diagnosis through disease indices (Hagnestam et al., 2007). The indices were categorical variables for time intervals before and after the diagnosis, modeling the time of every test milking relative to the day of diagnosis. For reproductive disorders, metabolic disorders, and claw disorders, the indices had 5 categories: the first 4 were TD milk yields measured $>1$ mo before diagnosis, $<1$ mo before diagnosis, $<1$ mo after diagnosis, and in the period thereafter. Cows that had not contracted any of the disorders included in a complex were given a fifth category. Because calving disorders obviously only appeared early in lactation, that index had 3 categories: within 1 mo after diagnosis, $>1$ mo after diagnosis, and not affected.

Housing system indicated whether the cow was kept in the tie-stall barn or the free-stall barn on the TD. A third class was used to define TD on which information on housing system was missing.

In the model for primiparous cows, the indices for metabolic and calving disorders were excluded because there were very few cases and because the effect was nonsignificant $(P>0.05)$, respectively. Parity was excluded for obvious reasons. The residuals were tested for normality using a quantile-quantile plot, and were judged as being close to the normal distribution.

\section{Estimation of Milk Loss}

TD Milk Loss. Test-day milk loss was expressed relative to milk yield on TD free of SCM. In lactation wk 2 to 44, a threshold of 50,000 cells/mL was used to distinguish between healthy TD and TD affected by SCM. This threshold was suggested by Hortet and Seegers (1998) and was based on studies on SCC in bacteriologically negative cultures: Laevens et al. (1997) who reported an SCC of 49,000 cells/mL in composite milk samples and Schepers et al. (1997) who found SCC around 14,000 cells/mL in quarter foremilk samples.

Higher thresholds of 175,000 and 200,000 cells/mL in primiparous and multiparous cows, respectively, were applied in the first week of lactation, because SCC is elevated in the colostrum period irrespective of whether the cow is infected with mastitis (Dohoo and Meek, 1982). These thresholds were defined based on bacteriological cultures of milk samples taken routinely in the research herd in the first week of lactation from the fall of 1997 until the fall of 2000. Distributions of $\log _{2}$-transformed SCC in composite milk, sampled on bacteriologically positive and negative TD, respectively, clearly overlapped in primiparous as well as in multiparous cows, and thresholds were therefore defined as an intermediate value between the medians of the distributions.

Daily milk loss associated with increased SCC, in different stages of lactation, was calculated based on the regression coefficients of primiparous and multiparous cows, and was expressed in both absolute and relative 
Table 3. Regression coefficients of daily milk yield on $\log _{2}$-transformed SCC in primiparous and multiparous cows, based on all test-day records free of clinical mastitis (data set A)

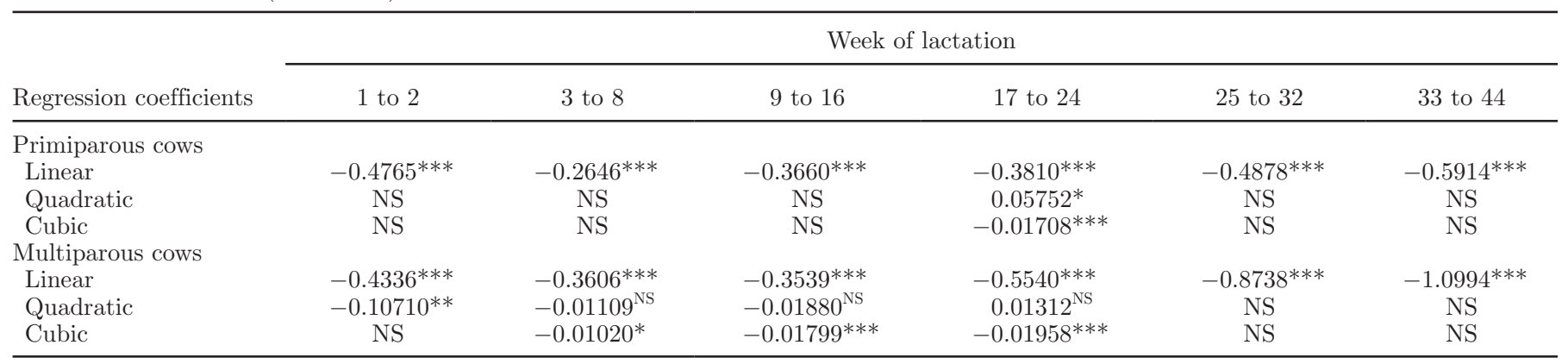

${ }^{*} P<0.05 ;{ }^{* *} P<0.01 ;{ }^{* * *} P<0.001 ; \mathrm{NS}=$ nonsignificant.

terms. Yield loss was expressed relative to different thresholds in lactation wk 1 and 2, even though it was calculated based on the same regression coefficient. There were, however, too few TD records in these weeks to allow them to be analyzed separately.

Loss over $305 \boldsymbol{d}$. Lactational milk loss was calculated as the difference between production of cows affected with SCM and healthy cows, and was calculated based on the regression coefficients. Weekly milk loss was weighted by the prevalence of SCM in each week of lactation, which varied between 33 and $83 \%$ and 43 and $95 \%$ in primiparous and multiparous cows, respectively. Lactational milk loss thus expressed the loss in an average lactation affected by SCM. Affected TD were assigned an SCC corresponding to the weekspecific geometric mean of TD with SCC above the thresholds, whereas healthy TD were assigned an SCC corresponding to the week-specific geometric mean of TD with SCC below the thresholds (Figure 1).

\section{RESULTS AND DISCUSSION}

The relationship between daily milk yield and $\log _{2^{-}}$ transformed SCC was influenced by stage of lactation and parity of the cow in both data sets (Tables 3 and 4). Generally, only first-order regressions were significant, except for multiparous cows in data set A.

\section{Daily Milk Loss Estimated from TD Free of CM}

Lactation Stage. Production loss related to an increase in SCC became more severe as lactation progressed, which would give rise to less-persistent lactation curves of affected cows. The most negative regression coefficients were found in lactation wk 33 to 44 irrespective of parity, indicating that an increase in SCC has the largest effect on milk yield in late lactation. Similar results have previously been reported (Hortet et al., 1999; Bennedsgaard et al., 2003). It has been suggested (Hortet et al., 1999) that poorer udder health status, caused by increased exposure to pathogens, increased prevalence of infection, and subsequent permanent glandular damage from previous infections, is responsible for the higher milk loss associated with an increase in SCC in late lactation. To test this explanation, we excluded lactations directly preceded by a lactation affected by $\mathrm{CM}$ from data set $\mathrm{B}$ and applied the model to TD sampled from multiparous cows. This analysis rendered regression coefficients that were similar to those obtained from data set B (results not shown). Milk loss related to an increase in SCC was, consequently, highest toward the end of lactation, both in cows with and cows without a history of CM. Consequently, our results do not support the hypothesis proposed by Hortet et al. (1999). Therefore, we suggest that large milk loss in late lactation is related to the fact that the udder is in a catabolic state. The degenerative process taking place might influence

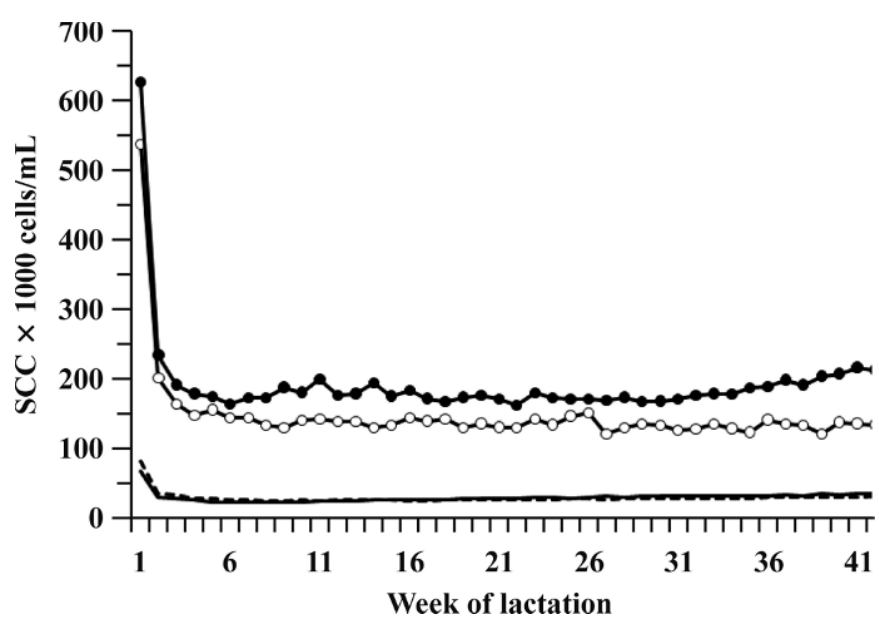

Figure 1. Average SCC (geometric mean) in different weeks of lactation in primiparous (---) and multiparous (-) cows without mastitis, and in primiparous (-O-) and multiparous (--) cows with subclinical mastitis. 
Table 4. Regression coefficients of milk yield on $\log _{2}$-transformed SCC in primiparous and multiparous cows, based on test-day records sampled in lactations free of clinical mastitis (data set B)

\begin{tabular}{|c|c|c|c|c|c|c|}
\hline Regression coefficients & \multicolumn{6}{|c|}{ Week of lactation } \\
\hline $\begin{array}{l}\text { Multiparous cows } \\
\text { Linear }\end{array}$ & $-0.7770^{* * *}$ & $-0.5134^{* * *}$ & $-0.5137^{* * *}$ & $-0.6777^{* * *}$ & $-0.9584^{* * *}$ & $-1.1873^{* * *}$ \\
\hline
\end{tabular}

*** $P<0.001$.

both the udder's ability to repair itself after infection and the compensatory ability of uninfected quarters. The compensatory ability of uninfected quarters has indeed been found to be lower in late than in early lactation (Hamann and Reichmuth, 1990). Hamann and Reichmuth (1990) argued that the potential for yield compensation is related to the number and activity of secretory cells, supporting our reasoning. It may be speculated that the relationship between SCC and milk yield in an affected quarter is always the same, but that better compensatory ability of uninfected quarters in early lactation masks some of the loss, and, when milk loss is estimated on udder total milk, milk loss will appear to be highest in late lactation.

The weakest association between SCC and daily milk yield was found in lactation wk 3 to 8 and 3 to 16 in primiparous and multiparous cows, respectively. This was a surprising finding, because cows usually reach peak production within the same period. Increased production can cause impairment of the immune system due to metabolic stress (van Knegsel et al., 2007). Søndergaard et al. (2002) reported high positive genetic correlations between mobilization of body reserves and SCC. When cows are in negative energy balance, body fat is converted to ketone bodies, and hyperketonemia has been suggested to be one of the most important factors causing impairment of the udder defense mechanisms (Suriyasathaporn et al., 2000; Janosi et al., 2003). Cows are in negative energy balance until approximately wk 7 to 9 of lactation (Suriyasathaporn et al., 2000). Cows are, consequently, more susceptible to udder infection in early lactation, and when affected, a more severe depression of milk yield would be expected to occur. This was not observed in the present study. On the contrary, more than $50 \%$ of all TD in this period, in primiparous as well as in multiparous cows, had an SCC $<50,000$ cells $/ \mathrm{mL}$, and the lowest regression coefficients were obtained. The low SCC can, however, partly be explained by a dilution effect brought about by high milk yield around peak production.

Parity. Multiparous cows had a higher milk loss when SCC increased than did primiparous cows (Tables 5 and 6), confirming the findings of previous studies (Hortet et al., 1999; Koldeweij et al., 1999; Bennedsgaard et al., 2003). Considering that the median SCC in later parts of lactation in multiparous cows was more than twice that in primiparous cows (Tables 1 and 2) and that most cows in a herd are in second or later lactations, it can be concluded that the majority of the milk loss caused by SCM in a herd is suffered by multiparous cows in late lactation.

Daily milk loss at an SCC of 500,000 cells/mL ranged from 0.7 to $2.0 \mathrm{~kg}$ in primiparous cows, depending on stage of lactation. In the studies reviewed by Hortet

Table 5. Absolute milk yield $(\mathrm{kg})$ at various SCC $\left(\times 10^{3}\right.$ cells $\left./ \mathrm{mL}\right)$, expressed as deviation from the amount of milk produced given an SCC of 175,000 or 200,000 cells $/ \mathrm{mL}$ in lactation wk 1 (primiparous and multiparous cows, respectively), and an SCC of 50,000 cells/mL in later lactation

\begin{tabular}{|c|c|c|c|c|c|c|c|}
\hline \multirow[b]{2}{*}{ SCC } & \multicolumn{7}{|c|}{ Week in lactation } \\
\hline & 1 & 2 & 3 to 8 & 9 to 16 & 17 to 24 & 25 to 32 & 33 to 44 \\
\hline 200 & -0.1 & -1.0 & -0.5 & -0.7 & -0.7 & -1.0 & -1.2 \\
\hline 500 & -0.7 & -1.6 & -0.9 & -1.2 & -1.3 & -1.6 & -2.0 \\
\hline 1,000 & -1.2 & -2.1 & -1.1 & -1.6 & -2.0 & -2.1 & -2.6 \\
\hline 200 & NA & -0.9 & -0.7 & -0.8 & -1.1 & -1.7 & -2.2 \\
\hline 500 & -1.1 & -2.0 & -1.4 & -1.6 & -2.1 & -2.9 & -3.7 \\
\hline 1,000 & -2.1 & -3.1 & -2.1 & -2.5 & -3.1 & -3.8 & -4.8 \\
\hline
\end{tabular}

${ }^{1} \mathrm{NA}=$ not applicable. 
Table 6. Relative milk yield $(\%)$ at various SCC $\left(\times 10^{3}\right.$ cells $\left./ \mathrm{mL}\right)$, expressed relative to the amount of milk produced given an SCC of 175,000 or 200,000 cells $/ \mathrm{mL}$ in lactation wk 1 (primiparous and multiparous cows, respectively), and an SCC of 50,000 cells/mL in later lactation

\begin{tabular}{|c|c|c|c|c|c|c|c|}
\hline \multirow[b]{2}{*}{$\mathrm{SCC}$} & \multicolumn{7}{|c|}{ Week in lactation } \\
\hline & 1 & 2 & 3 to 8 & 9 to 16 & 17 to 24 & 25 to 32 & 33 to 44 \\
\hline \multicolumn{8}{|c|}{ Primiparous cows } \\
\hline 200 & -0.4 & -3.9 & -1.7 & -2.5 & -2.4 & -3.7 & -5.2 \\
\hline 500 & -3.1 & -6.5 & -2.9 & -4.1 & -4.6 & -6.1 & -8.6 \\
\hline 1,000 & -5.1 & -8.4 & -3.8 & -5.3 & -7.3 & -8.0 & -11.2 \\
\hline 200 & NA & -3.1 & -2.1 & -2.3 & -4.0 & -6.9 & -10.9 \\
\hline 500 & -3.8 & -6.8 & -3.9 & -4.8 & -7.2 & -11.4 & -18.1 \\
\hline 1,000 & -7.5 & -10.5 & -5.9 & -7.7 & -10.7 & -14.9 & -23.6 \\
\hline
\end{tabular}

${ }^{1} \mathrm{NA}=$ not applicable.

and Seegers (1998), daily milk loss at 400,000 cells/mL varied between 0.8 and $3.1 \mathrm{~kg}$ in primiparous cows. In multiparous cows, milk daily loss at 500,000 cells $/ \mathrm{mL}$ was 1.1 to $3.7 \mathrm{~kg}$, whereas Hortet and Seegers (1998) reported a daily milk loss ranging from 1.0 to $3.0 \mathrm{~kg}$ at an SCC of 400,000 cells $/ \mathrm{mL}$. All the estimates from the present study fell within, or were close to, the range of loss reported by Hortet and Seegers (1998). In most of the reviewed literature (Hortet and Seegers, 1998), TD affected with CM were included in the analyses but were not accounted for in the models. The observed relationship between SCC and milk yield therefore originated from both CM and SCM. The milk loss estimated in the present study should, therefore, be expected to be lower than that given by Hortet and Seegers (1998). Hortet et al. (1999) excluded TD following CM treatment and found the same trend of increasing milk loss in multiparous cows as lactation progressed. Besides the fact that Hortet et al. (1999) did not find any influence of stage of lactation on daily milk loss in primiparous cows, their estimates corresponded well with the results obtained in the present study.

\section{Daily Milk Loss Estimated from TD Sampled in Lactations Free of CM}

In primiparous cows, the size of the regression coefficients obtained from data set B was consistent with the linear regression coefficients estimated from data set A (Tables 3 and 4). In multiparous cows, regression coefficients obtained from data set B were more negative and, thus, indicated a more severe milk loss. An increase in SCC, consequently, had a certain relationship with milk yield in primiparous cows, irrespective of whether the cow developed $\mathrm{CM}$ in the lactation or not, whereas in multiparous cows, an increase in SCC was associated with a higher milk loss in lactations in which the cow did not develop CM.
As the regression coefficients estimated from the 2 data sets were similar in primiparous cows, the observed difference between the results obtained for multiparous cows was most likely attributable to some factor unique for multiparous cows. By definition, multiparous cows have had at least one preceding lactation. One hypothesis might be that if the preceding lactation was affected by $\mathrm{CM}$, the immune response might be faster and more efficient in the current lactation, such that the reaction to increased SCC becomes less severe. To investigate if the lower milk loss estimated from data set A was caused by a carry-over effect of CM from the previous lactation, a stratified analysis was conducted on a restricted data set in which all TD sampled in lactations immediately preceded by a lactation where CM occurred had been removed from data set $\mathrm{A}$. The obtained regression coefficients were more negative than those estimated from data set A, except in lactation stage 4 (results not shown). Thus, the fact that milk loss in multiparous cows was less severe when the analysis was based on TD free of CM (data set A) than when it was based on TD sampled in lactations free of CM (data set B) was, at least to some extent, explained by the fact that some of the cows included in data set A had a history of CM. Further research is needed to answer whether CM actually can cause a limited amnestic response.

\section{Linear Relationship Between Milk Yield and SCC}

Regression coefficients estimated from data set B indicated a linear relationship between daily milk yield and $\log _{2}$-transformed SCC (Table 4). Curvilinear regressions were identified in data set A (Table 3). Visual inspection did, however, reveal that the relationship was very close to linear in all stages of lactation also in data set A. Significant effects of quadratic and cubic terms of transformed SCC have previously been identified 
(Bartlett et al., 1990; Koldeweij et al., 1999), but these studies have also reported a very limited contribution of these effects. Consequently, inclusion of quadratic and cubic terms can be assumed to be of minor biological importance, and linear regression is sufficient to describe the relationship between milk production and transformed SCC.

\section{Lactational Milk Loss}

The 305-d milk yield of healthy cows was estimated at 8,354 and $8,630 \mathrm{~kg}$ of milk in primiparous and multiparous cows, respectively. Milk loss in the average lactation affected with SCM was estimated at $155 \mathrm{~kg}$ of milk in primiparous cows and $445 \mathrm{~kg}$ of milk in multiparous cows. Expressed in relative terms, SCM caused a production loss of 1.9 and $5.2 \%$ in primiparous and multiparous cows, respectively.

The 305-d milk loss was obtained by summarizing weekly milk losses in cows affected by SCM weighted by the prevalence of SCM in each week of lactation. The presented estimates were, consequently, dependent on the frequency of SCM in the herd, and the estimates might not be representative for herds with a higher or lower incidence of SCM. This is just one way of summarizing the temporal milk loss associated with SCM and other ways can certainly be envisioned. Our estimates were based on actual data, and other approaches would have required even more assumptions.

In the literature (Hortet and Seegers, 1998), lactational yield loss caused by SCM is often expressed as the reduction in lactational milk yield per doubling of the lactational geometric mean SCC. Analyzing lactational mean values will implicitly ignore the dynamics in SCC that occur throughout lactation. It will also smooth out any SCC peaks. If such peaks in SCC are associated with extensive milk loss, then lactational milk loss will be underestimated. Further bias is created if lactational mean values are calculated based on monthly TD, because infections with a short duration may be missed. Escherichia coli, for instance, has been reported to give rise to a peak in SCC in connection with CM diagnosis, after which SCC shows a rather rapid decline and returns to close to its premastitic level in 3 to 4 wk (Pyörälä et al., 1994; De Haas et al., 2002). Milk loss caused by environmental pathogens might therefore go undetected if estimates of lactational yield loss are based on monthly SCC records.

An alternative strategy to estimate the lactational milk loss would have been to establish SCC patterns associated with SCM in different weeks of lactation and estimate the associated milk loss. Such an approach is, however, associated with 2 issues: first, the problem of defining what a case of SCM really is in terms of
SCC would be encountered, and, second, more frequent records of SCC than were available for this study would have been required to capture short-term fluctuations in SCC.

\section{Different Approaches to Adjust for CM}

Production loss caused by SCM cannot be estimated correctly using SCC unless CM is accounted for in the analysis. If CM is ignored, the total effect of mastitis will be estimated, and such an analysis will provide a less accurate estimate of the specific milk loss caused by SCM. Two general strategies to control for CM in the analysis have been applied in previous studies: excluding TD records or including adjustment terms in the model.

Different approaches have been taken regarding exclusion of records. In the present paper, 2 strategies were tested. In data set A, TD affected with CM were discarded and in data set B TD sampled in lactations affected with CM were excluded. The chosen approach clearly affected the outcome of the analysis. A third strategy was applied by Hortet et al. (1999). They excluded all TD records sampled after CM treatment. The estimates obtained by Hortet et al. (1999) corresponded well with the results obtained from data set A in the present study. It thus seems to be sufficient to exclude only TD sampled between CM diagnosis and $8 \mathrm{~d}$ afterwards to obtain estimates that are free of the influence of a preceding case of CM (in the same lactation).

Exclusion of records obviously decreases the size of the data set. Some studies have therefore instead chosen to adjust for CM in their models. This has been done by including binary independent variables indicating presence or absence of CM or CM treatment (Deluyker et al., 1993; Bennedsgaard et al., 2003). A more appropriate approach would be to adjust TD yields with respect to the timing of CM. This modeling strategy has previously been applied when estimating the effects of CM on production (Gröhn et al., 2004; Hagnestam et al., 2007). The main benefit achieved by inclusion of such a mastitis index in the model is that TD yields are corrected not only for the cow having had CM, but also for the fact that the effect of CM on TD yield varies depending on how many weeks before or after diagnosis the cow is sampled. In the initial analyses, we included an interaction term between a mastitis index and stage of lactation, which Hagnestam et al. (2007) showed was most appropriate, but this made the model too complicated and gave rise to convergence problems. The simpler approach of eliminating records was therefore chosen. 


\section{Definition of SCM}

We used the same threshold to define SCM in lactation wk 2 to 44 , even though SCC increased over lactation. Dohoo and Meek (1982) and Sheldrake et al. (1983) suggested that increasing SCC during lactation is not a physiological phenomenon per se, but a consequence of increasing prevalence of subclinical infection as lactation progresses. The use of a constant threshold to define SCM from lactation wk 2 and onward can thus be considered appropriate. A peak in SCC occurs after calving, regardless of whether the cow is infected (Dohoo and Meek, 1982). Using the same threshold then as in the rest of lactation would thus have lead to overestimation of the milk loss in the first week of lactation, and a higher threshold was therefore chosen.

Initially, an approach was taken in which all TD within the same lactation had to have an SCC below 175,000 or 200,000 cells $/ \mathrm{mL}$ in the first week of lactation (primiparous and multiparous cows, respectively), and below 50,000 cells/mL in subsequent lactation weeks in order for a lactation to qualify as free of SCM. This criterion was met by very few lactations and was abandoned in favor of the week-specific geometric mean SCC for TD affected by SCM and healthy TD.

The applied approach for defining SCM was based on classifying individual TD as affected or unaffected according to their SCC. However, TD SCC is affected by several factors. Infectious status of the mammary gland is clearly the most important one, but season, stress, and management mishaps also assert an effect on SCC (Dohoo and Meek, 1982; Reneau, 1986). Individual TD results are therefore rather inconclusive. It has been suggested (Dohoo and Meek, 1982; Reneau, 1986; De Haas et al., 2004) that SCM should be defined based on patterns of SCC over a series of consecutive TD to increase the accuracy of diagnosis. De Haas et al. (2004) derived the SCC patterns of clinically infected cows based on 3 to 5 TD results, recorded with 3 - to 4 -wk intervals. With such long sampling intervals, actually detecting an increased SCC will depend on when infection occurred (with respect to sampling), but also on the duration of the increase in SCC, as pointed out by De Haas et al. (2004). If this method were to be applied to SCM, SCM could heal spontaneously or turn into a clinical infection before diagnosis based on a completed SCC pattern could be made. A shorter time interval between TD is thus required if diagnosis of SCM is to be based on SCC patterns. Patterns should preferably be based on daily observations, because SCC fluctuates from day to day (Reneau, 1986).

Modern, computerized milking systems can provide information on SCC from individual milkings, and offer the opportunity to establish SCC patterns based on information sampled at very short time intervals. Research is needed to answer if, and with what accuracy, such detailed patterns of SCC could be used to detect SCM at an early stage of infection. If actions could be taken to prevent SCM from developing further, production loss could most certainly be reduced.

\section{CONCLUSIONS}

Daily milk loss at an SCC of 500,000 cells/mL ranged from 0.7 to $2.0 \mathrm{~kg}$ (3 to $9 \%$ ) in primiparous cows, depending on stage of lactation. In multiparous cows, corresponding loss was 1.1 to $3.7 \mathrm{~kg}$ (4 to 18\%). Somatic cell count had the same association with milk yield in primiparous cows, irrespective of whether the cow developed $\mathrm{CM}$ in the lactation, whereas in multiparous cows, an increase in SCC was associated with a higher milk loss in lactations in which the cow did not develop CM. The most extensive daily milk loss related to an increase in SCC was observed in late lactation. For a given increase in SCC, daily milk loss was almost twice as large in multiparous cows as in primiparous cows. In addition, the 305-d milk loss in the average lactation affected with SCM was almost 3 times larger in multiparous cows. Multiparous cows in late lactation can be expected to be responsible for the majority of the herd-level production loss caused by SCM, because of the high incidence of SCM and the extensive milk loss associated with increased SCC within this period. Preventive measures, therefore, need to focus on reducing the incidence of SCM in multiparous cows in the latter part of lactation.

\section{ACKNOWLEDGMENTS}

Financial support from the Swedish Farmers' Foundation for Agricultural Research (Stockholm, Sweden) is greatly appreciated. The research herd staff is acknowledged for collecting and providing data for the study.

\section{REFERENCES}

Ali, T. E., and L. R. Schaeffer. 1987. Accounting for covariances among test day milk yields in dairy cows. Can. J. Anim. Sci. 67:637-644.

Bartlett, P. C., G. Y. Miller, C. R. Anderson, and J. H. Kirk. 1990. Milk production and somatic cell count in Michigan dairy herds. J. Dairy Sci. 73:2794-2800.

Beaudeau, F., H. Seegers, C. Fourichon, and P. Hortet. 1998. Association between milk somatic cell counts up to 400,000 cells/ $\mathrm{mL}$ and clinical mastitis in French Holstein cows. Vet. Rec. 143:685-687.

Bendixen, P. H., B. Vilson, I. Ekesbo, and D. B. Astrand. 1988. Disease frequencies in dairy cows in Sweden. Mastitis 5:263-274.

Bennedsgaard, T. W., C. Enevoldsen, S. M. Thamsborg, and M. Vaarst. 2003. Effect of mastitis treatment and somatic cell counts on milk yield in Danish organic dairy cows. J. Dairy Sci. 86:3174-3183. 
De Haas, Y., H. W. Barkema, and R. F. Veerkamp. 2002. The effect of pathogen-specific clinical mastitis on the lactation curve for somatic cell count. J. Dairy Sci. 85:1314-1323.

De Haas, Y., R. F. Veerkamp, H. W. Barkema, Y. T. Gröhn, and Y. H. Schukken. 2004. Associations between pathogen-specific cases of clinical mastitis and somatic cell count patterns. J. Dairy Sci. 87:95-105.

Deluyker, H. A., J. M. Gay, and L. D. Weaver. 1993. Interrelationships of somatic-cell count, mastitis, and milk-yield in a low somatic-cell count herd. J. Dairy Sci. 76:3445-3452.

Dohoo, I. R., and S. W. Martin. 1984. Disease, production and culling in Holstein-Friesian cows. III. Disease and production as determinants of disease. Prev. Vet. Med. 2:671-690.

Dohoo, I. R., and A. H. Meek. 1982. Somatic cell counts in bovine milk. Can. Vet. J. 23:119-125.

Fitzpatrick, J. L., F. J. Young, D. Eckersall, D. N. Logue, C. J. Knight, and A. Nolan. 1998. Recognising and controlling pain and inflammation in mastitis. Pages 36-44 in Proc. Br. Mastitis Conf.

Fourichon, C., H. Seegers, N. Bareille, and F. Beaudeau. 1999. Effects of disease on milk production in the dairy cow: A review. Prev. Vet. Med. 41:1-35.

Gröhn, Y. T., D. J. Wilson, R. N. Gonzalez, J. A. Hertl, H. Schulte, G. Bennett, and Y. H. Schukken. 2004. Effect of pathogenspecific clinical mastitis on milk yield in dairy cows. J. Dairy Sci. 87:3358-3374

Hagnestam, C., U. Emanuelson, and B. Berglund. 2007. Yield losses associated with clinical mastitis occurring in different weeks of lactation. J. Dairy Sci. 90:2260-2270.

Hamann, J., and J. Reichmuth. 1990. Compensatory milk production within the bovine udder: Effects of short-term non-milking of single quarters. J. Dairy Res. 57:17-22.

Hortet, P., F. Beaudeau, H. Seegers, and C. Fourichon. 1999. Reduction in milk yield associated with somatic cell counts up to 600000 cells $/ \mathrm{mL}$ in French Holstein cows without clinical mastitis. Livest. Prod. Sci. 61:33-42.

Hortet, P., and H. Seegers. 1998. Calculated milk production losses associated with elevated somatic cell counts in dairy cows: Review and critical discussion. Vet. Res. 29:497-510.

Huijps, K., T. J. Lam, and H. Hogeveen. 2008. Costs of mastitis: Facts and perception. J. Dairy Res. 75:113-120.

International Dairy Federation. 1997. Recommendations for presentation of mastitis-related data. Bull. IDF 321:6-25.

Janosi, S., M. Kulcsar, P. Korodi, L. Katai, J. Reiczigel, S. J. Dieleman, J. A. Nikolic, G. Salyi, P. Ribiczey-Szabo, and G. Huszenicza. 2003 Energy imbalance related predisposition to mastitis in group-fed high-producing postpartum dairy cows. Acta Vet. Hung. 51:409424.

Koldeweij, E., U. Emanuelson, and L. Janson. 1999. Relation of milk production loss to milk somatic cell count. Acta Vet. Scand. $40: 47-56$.

Laevens, H., H. Deluyker, Y. H. Schukken, L. De Meulemeester, R. Vandermeersch, E. De Muêlenaere, and A. De Kruif. 1997. Influence of parity and stage of lactation on the somatic cell count in bacteriologically negative dairy cows. J. Dairy Sci. 80:32193226 .
Ma, Y., C. Ryan, D. M. Barbano, D. M. Galton, M. A. Rudan, and K. J. Boor. 2000. Effects of somatic cell count on quality and shelf-life of pasteurized fluid milk. J. Dairy Sci. 83:264-274.

Olori, V. E., S. Brotherstone, W. G. Hill, and B. J. McGuirk. 1997. Effect of gestation stage on milk yield and composition in Holstein Friesian dairy cattle. Livest. Prod. Sci. 52:167-176.

Østergaard, S., and Y. T. Gröhn. 1999. Effects of diseases on test day milk yield and body weight of dairy cows from Danish research herds. J. Dairy Sci. 82:1188-1201.

Politis, I., and K. F. Ng-Kwai-Hang. 1988. Association between somatic cell count of milk and cheese-yielding capacity. J. Dairy Sci. $71: 1720-1727$

Pyörälä, S., L. Kaartinen, H. Käck, and V. Rainio. 1994. Efficacy of two therapy regimens for treatment of experimentally induced Escherichia coli mastitis in cows. J. Dairy Sci. 77:453-461.

Reneau, J. K. 1986. Effective use of dairy herd improvement somatic cell counts in mastitis control. J. Dairy Sci. 69:1708-1720.

Roche, J. R. 2003. Effect of preonancy on milk production and bodyweight from identical twin study. J. Dairy Sci. 86:777-783.

Schepers, A. J., T. J. G. M. Lam, Y. H. Schukken, J. B. M. Wilmink, and W. J. A. Hanekamp. 1997. Estimation of variance components for somatic cell counts to determine thresholds for uninfected quarters. J. Dairy Sci. 80:1833-1840.

Sheldrake, R. F., R. J. T. Hoare, and G. D. McGregor. 1983. Lactation stage, parity, and infection affecting somatic cells, electrical conductivity, and serum albumin in milk. J. Dairy Sci. 66:542547

Singer, J. D. 1998. Using SAS PROC MIXED to fit multilevel models, hierarchical models, and individual growth models. J. Educ. Behav. Stat. 24:323-355.

Sogstad, A. M., O. Osteras, and T. Fjeldaas. 2006. Bovine claw and limb disorders related to reproductive performance and production diseases. J. Dairy Sci. 89:2519-2528.

Sogstad, A. M., O. Osteras, T. Fjeldaas, and A. O. Refsdal. 2007. Bovine claw and limb disorders at claw trimming related to milk yield. J. Dairy Sci. 90:749-759.

Søndergaard, E., M. K. Sørensen, I. L. Mao, and J. Jensen. 2002. Genetic parameters of production, feed intake, body weight, body composition, and udder health in lactating dairy cows. Livest. Prod. Sci. 77:23-34.

Spörndly, R., ed. 1999. Fodertabeller för idisslare (Nutrition Requirements for Ruminants). Publ. No. 247. Swedish Univ. Agric. Sci., Dept. Anim. Nutr. Health, Uppsala, Sweden.

Steeneveld, W., H. Hogeveen, H. W. Barkema, J. van den Broek, and R. B. M. Huirne. 2008. The influence of cow factors on the incidence of clinical mastitis in dairy cows. J. Dairy Sci. 91:1391-1402.

Suriyasathaporn, W., C. Heuer, E. N. Noordhuizen-Stassen, and Y. H. Schukken. 2000. Hyperketonemia and the impairment of udder defense: A review. Vet. Res. 31:397-412.

van Knegsel, A. T. M., G. de Vries Reilingh, S. Meulenberg, H. van den Brand, J. Dijkstra, B. Kemp, and H. K. Parmentier. 2007. Natural antibodies related to energy balance in early lactation dairy cows. J. Dairy Sci. 90:5490-5498. 